\title{
Estimation of growth curve parameters in Beetal goats
}

\author{
Abdul Waheed', Muhammad Sajjad Khan', Safdar Ali' and Muhammad Sarwar ${ }^{2}$ \\ 'Department of Animal Breeding and Genetics, Faculty of Animal Husbandry, University of Agriculture, Faisalabad, \\ Pakistan, ${ }^{2}$ Institute of Animal Feed and Technology, University of Agriculture, Faisalabad, Pakistan
}

\begin{abstract}
Growth data from birth to one year of age on 120 Beetal goats, 30 animals on each farm, including Livestock Experiment Station (LES) Rakh Kheirewala, LES Rakh Ghulaman, LES Alladad and LPRI Bahadurnagar, Okara, Pakistan, were recorded and analysed for estimating growth curve parameters: predicted live weight, "a«, turning point of growth, »b« and rate of growth »k« by using Brody and Gompertz mathematical functions employing non-linear regression models. Estimates of the growth curve parameters »a«, »b« and »k« were 29.1, 0.916 and 0.108 for Brody and 23.4, 1.984 and 0.258 for Gompertz functions, respectively. The corresponding values of determination coefficient and mean absolute deviation for these models were 99.8 and 99.8 percent and 0.0061 and 0.0050 , respectively. Flock significantly affected parameter »b» of Brody and Gompertz models. Sex did not affect any of the parameters in both models. Type of birth was a significant source of variation for parameter "b/ in the Brody model. The determination coefficient showed that both the models efficiently explained the growth of Beetal kids.
\end{abstract}

Keywords: growth curve, Beetal goats, Brody and Gompertz functions

\section{Zusammenfassung}

\section{Abschätzung von Wachstumskurven-Parametern von Beetal-Ziegen}

Die Wachstumsdaten von 120 Beetal Ziegen aus Pakistan von der Geburt bis zu einem Alter von einem Jahr wurden untersucht und hinsichtlich folgender WachstumskurvenParameter ausgewertet: geschätztes Lebendgewicht »a«, Wachstumsscheitelpunkt »b« und Wachstumsgeschwindigkeit »k«. Dazu wurden die mathematischen Funktionen von Brody und Gompertz unter Einsatz von nichtliearen Regressionsmodellen genutzt. Die Schätzungen der Wachstumskurven-Parameter »a«, »b « und »k« lauteten 29,1, 0,916 und 0,108 für die BrodyFunktion sowie 23,4, 1,984 und 0,258 für die Gompertz-Funktion. Die entsprechenden Werte für das Bestimmtheitsmaß und die mittlere absolute Abweichung für diese Modelle betrugen 99,8 und 99,8\% bzw. 0,0061 und 0,0050. Die Herde beeinflusst Parameter »b« der Modelle von Brody und Gompertz signifikant,während in beiden Modellen das Geschlecht keinen der Parameter beeinflusste. Die Art der Geburt (einzeln/mehrfach) war eine signifikante Quelle der Schwankungen für Parameter »b« im Brody-Modell. Das Bestimmtheitsmaß zeigte, dass beide Modelle das Wachstum der Beetal-Ziegenkitze wirksam erklären können.

Schlüsselwörter: Wachtumskurve, Beetal Ziegen, Brody und Gompertz Funktionen 


\section{Introduction}

Growth is a biological phenomenon that can be interpreted mathematically, is an economically important trait of farm animals. It is a time(age) dependent change manifested in the weight or size of organ, composition of tissue/organ, size of cell and number as well as in live weight (Eisen 1976).

Growth curve is the graph of weight as a function of age on time. The curve elaborates gradual changes taking place in animal's body with the passage of time. This is often sigmoid in shape. Sigmoid curve has three phases: preparing, increasing and quietness. In first phase, growing starts at a specific point and increases gradually. In second phase, curve adopts somewhat linear shape up to distortion point. In the last phase, the curve reaches asymptote.

Different mathematical growth models have been used to define growth curve. Growth curve parameters provide information on growth characteristics. The most commonly used functions to estimate animal's growth have three to four parameters. The different models include: Brody (Brody 1945), Bertalanffy (Bertalanffy 1957) Richards (Richards 1959), Logistic (Nelder 1961) and Gompertz (Laird 1965). According to a number of researchers interpretation of growth varied according to breed and model (Akbas et al. 1999, Kocabas et al. 1997, Jenkins \& Leymaster 1993).

Growth curves find many a uses in farm animals. These curves have been used to estimate mature body weight and increase in liveweight in goat and sheep by many research workers (Kor et al. 2006, Jenkins \& Leymaster 1993, Nasholm \& Danell 1990, Nasholm 1990, Salah et al. 1988, Moore 1986).

Growth curve can be used for pre-selection of animal as it provides prediction of future growth at any age (Tekel et al. 2005). During the last few years studies on some growth curves and their use in environmental and breeding strategies have increased (Tatar et al. 2009, Tekel et al. 2005, Yeni 2003, Bananno et al. 1997).

Growth curve is used for evaluation of response to specific treatment over time, interaction between subpopulations and/or treatments and time and identifying heavier animals at younger age within population (Bathaei \& Leyroy 1996). Further, information on the growth pattern helps determine feeding and management plans and planning breeding strategies to improve the efficacy of whole growth process (Lambe et al. 2006). Knowledge about the factors influencing shape of growth curve and relationship among parameters is needed to enhance its efficiency.

Beetal is an important breed of goat in Pakistan consisting of $7.8 \%$ of total goat population in the country (Gop 2006). It is a preferred sacrificial animal. Study on growth curve of this breed in the country was lacking. Therefore, the present study was planned to define growth curve of Beetal goats using Brody and Gompertz mathematical models. The objectives of the research works were to estimate parameters of growth curve of Beetal goats using Brody and Gompertz models. 


\section{Materials and methods}

\section{Source of data}

Growth data on 120 Beetal goats at monthly intervals were recorded from birth to one year of age on four government farms: Livestock Experiment Station (LES), Rakh Kheirewala (RK), District Layyah, LES, Rakh Ghulaman (RG), District Bhakkar, LES, Alladad (AD), District Khanewal and Livestock Production Research Institute (LPRI), Bahadurnagar (BN), District Okara from December 2008 to November 2009. First two farms are located in the Thal area with arid conditions and scanty rainfall. The later two farms are located in the well irrigated area. On all of the four farms kid were fed their dam's milk in the morning and evening up to 120 days of age and then weaned. Grazing was allowed from 08:00 to 17:00 and water was offered to the animals twice a day. The animals were kept indoors at night. No concentrates were fed to the animals. 30 animals were recorded at each farm. The data comprised of birth weight and monthly weights of male and female kids from birth to one year of age. Sex of kid (male or female) and type of birth (single or twin) (TOB) were also recorded. The body weights were measured using spring balance.

\section{Statistical models}

The following non-linear regression models were used:

Brody model;

$$
Y=A\left(1-B e^{-k t}\right)+\varepsilon
$$

Gompertz model;

$$
Y=A e^{B e-k t}+\varepsilon
$$

where $Y$ is the observed live weight of the animal, $A$ is the predicted live weight, $B$ is the turning point of growth (t=0), $k$ is the rate of growth, $t$ is the time (birth to one year of age), $e$ is the base of natural logarithm and $\varepsilon$ is the random error.

Absolute mean residual deviation (MAD) was calculated according to Sarmento et al. (2006), which gives better adjustment, using the following formula:

$$
M A D=\frac{\sum\left|Y_{i}-\hat{Y}_{i}\right|}{n}
$$

where $Y_{i}$ is the observed value, $\hat{Y}$ is the estimated value and $n$ is the size of sample.

Fixed effects model was fitted to analyze the effect of different non-genetic factors affecting parameters in the growth curve. Following model was assumed for this purpose:

$$
Y_{i j k l}=\mu+F_{i}+\operatorname{Sex}_{j}+T O B_{k}+\operatorname{Sex} \times T O B_{j . k}+e_{i j k l}
$$

where $Y_{i j k l}$ is the estimated parameter of the growth curve, $F_{i}$ is the effect of $i$-th flock $(i=1 \ldots 4)$, Sex is the effect of $j$-th sex (1=male, $2=$ female), TOB ${ }_{k}$ is the effect of $k$-th type of birth (1=single, $2=$ twin), Sex $\times \mathrm{TOB}_{j . k}$ is the interaction between sex and type of birth and $e_{i j k l}$ is the random error. 


\section{Software and computing resources}

Microsoft Excel was used for entering and editing of data on the platform of MS Windows XP, using a P4 2.4 GHz CPU and 512 MB RAM. Also, for drawing graphs/curves, the same software was helpful. The parameters in the Brody and Gompertz model were estimated using nonlinear regression model running NLREG Version 6.5 (Sherrod 2008) software. MAD, a criterion to compare model, was calculated to find better adjustment (lower the MAD, better the adjustment) of the models. Analysis of variance for growth curve parameters and separation of means were done by Statistical Package for Social Sciences (SPSS 1999).

\section{Results}

Arithmetic means $(\mathrm{kg})$ and standard deviation of birth weight and monthly weights (month 1 to 12) are presented in Table 1. Birth weight in female and male Beetal kids averaged 2.6 \pm 0.48 and $2.7 \pm 0.48 \mathrm{~kg}$ and yearling weights averaged $20.7 \pm 1.54$ and $22.6 \pm 1.09 \mathrm{~kg}$, respectively (Table 1). The parameters ( $\pm s e)$ and coefficient of determination $\left(R^{2}\right)$ estimated by Brody and Gompertz models for live weight of Beetal kids, are presented in Table 2. Environmental factors affecting these parameters are given in Table 3. Environmental factors affecting parameters of Brody and Gompertz models are shown in Table 4 and Table 5 respectively. The estimates of the growth curve parameters: predicted weight "a«, turning point of growth »b« and rate of growth »k« for Brody and Gompertz functions are given in Table 6 and 7 respectively. The $\mathrm{R}^{2}$ values for these models were similar (99.79 and $99.76 \%$ ). Corresponding values of mean absolute deviation (MAD) were 0.0061 and 0.005 , respectively. Growth curves from different models are presented in Figure 1. Flock significantly $(P<0.001$ and $P<0.01)$ affected parameter $» b$ « in Brody and Gompertz model. On the other hand sex of kid had no effect on any of the parameters while TOB significantly affected »b « in Brody model (Table 3).

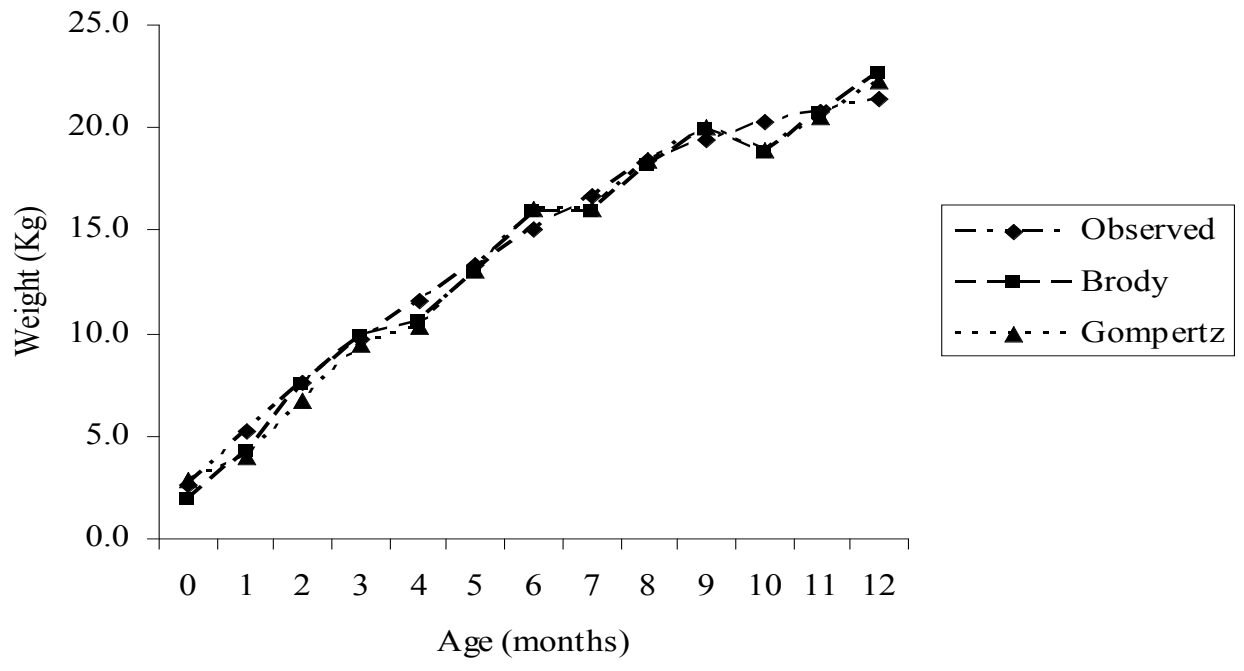

Figure 1

Observed and predicted growth curve in Beetal goats 
Table 1

Means $(\mathrm{kg})$ and standard deviations (SD) of growth traits of Beetal goats

\begin{tabular}{lcccc}
\hline Weight & Sex & Mean & N & SD \\
\hline Birth weight & Female & 2.6 & 60 & 0.48 \\
Month 1 & Male & 2.7 & 60 & 0.48 \\
& Female & 4.8 & 60 & 1.35 \\
Month 2 & Male & 5.5 & 60 & 1.31 \\
& Female & 7.1 & 60 & 1.71 \\
Month 3 & Male & 8.1 & 60 & 1.70 \\
& Female & 9.0 & 60 & 1.94 \\
Month 4 & Male & 10.3 & 60 & 2.00 \\
& Female & 10.8 & 60 & 2.09 \\
Month 5 & Male & 12.3 & 60 & 2.22 \\
& Female & 12.5 & 60 & 2.19 \\
Month 6 & Male & 14.2 & 60 & 2.36 \\
& Female & 14.0 & 60 & 2.29 \\
Month 7 & Male & 15.9 & 60 & 2.49 \\
& Female & 15.6 & 60 & 2.38 \\
Month 8 & Male & 17.5 & 60 & 2.73 \\
& Female & 17.2 & 60 & 2.10 \\
Month 9 & Male & 19.6 & 60 & 3.14 \\
& Female & 18.2 & 60 & 2.03 \\
Month 10 & Male & 20.4 & 60 & 2.73 \\
& Female & 19.1 & 60 & 1.78 \\
Month 11 & Male & 21.3 & 60 & 2.45 \\
& Female & 19.9 & 60 & 1.61 \\
Month 12 & Male & 21.6 & 60 & 2.00 \\
& Female & 20.7 & 60 & 1.54 \\
& Male & 22.1 & 60 & 1.90 \\
\hline
\end{tabular}

Table 2

Parameters of growth curve in different models for Beetal kids

\begin{tabular}{lccccccc}
\hline Model & \multicolumn{2}{c}{$\mathrm{a}$} & \multicolumn{2}{c}{$\mathrm{b}$} & \multicolumn{2}{c}{$\mathrm{k}$} & $\mathrm{R}^{2}$ \\
& constant & se & constant & se & constant & se & \\
\hline Brody & 29.13 & 1.1553 & 0.916 & 0.0065 & 0.1077 & 0.0083 & 99.79 \\
Gompertz & 23.39 & 0.4477 & 1.980 & 0.0504 & 0.2582 & 0.0119 & 99.76 \\
\hline
\end{tabular}

a: predicted weight, $b$ : turning point of growth, $k$ : rate of growth

In present study on Beetal goats, parameter »a« of Brody model in overall estimate had higher value than that of Gompertz model with slightly larger standards error. But parameter »b» in Gompertz model showed greater value than that of Brody's. Similarly parameter »k« was greater in Gompertz model (Table 2). While analyzing single factors for parameters of Brody model, it was found that only flock differences were significant for parameter »b«, while sex and TOB did not affect any of the parameters (Table 4). These differences might be due slight differences in flock management. For Gompertz model parameters, flock significantly affected all the three parameters. The differences for »a« were obvious, Alladad farm had the 
highest value, followed by Rakh Kheirewala, Bahadurnagar \& Rakh Ghulaman (Table 5). For parameter »b« Rakh Kheirewla had the greatest value, followed by Rakh Ghulaman, Alladad and Bahadurnagar farm. Again Rakh Kheirewala had greatest value for »k«, followed by Bahadurnagar, Rakh Ghulaman \& Alladad farm Table 5). When sexes were separated within flocks using Brody and Gompertz models, they did not differ at all (Table 6 and 7).

Table 3

Environmental factors affecting parameters of growth curve

\begin{tabular}{|c|c|c|c|c|c|c|}
\hline \multirow[t]{2}{*}{ Factor } & \multicolumn{3}{|c|}{ Brody } & \multicolumn{3}{|c|}{ Gompertz } \\
\hline & a & B & k & a & b & K \\
\hline Flock & ns & $* * *$ & ns & ns & $* *$ & ns \\
\hline Sex & ns & ns & ns & ns & ns & ns \\
\hline Type of birth & ns & $*$ & ns & ns & ns & ns \\
\hline
\end{tabular}

${ }^{*} P<0.05,{ }^{* *} P<0.01,{ }^{* * *} P<0.001$, ns: non significant, a: predicted weight, b: turning point of growth, $\mathrm{k}$ : rate of growth

Table 4

Single factor analysis for parameters in Brody model

\begin{tabular}{|c|c|c|c|c|c|c|c|}
\hline \multirow[t]{2}{*}{ Factor } & & \multicolumn{2}{|c|}{$a$} & \multicolumn{2}{|c|}{ b } & \multicolumn{2}{|c|}{$\mathrm{k}$} \\
\hline & & Constant & se & Constant & se & Constant & se \\
\hline \multirow[t]{2}{*}{ Sex } & Male & $32.60^{A}$ & 1.46 & $0.9223^{A}$ & 0.0052 & $0.2750^{A}$ & 0.0079 \\
\hline & Female & $33.30^{A}$ & 1.96 & $0.9210^{A}$ & 0.0060 & $0.2492^{A}$ & 0.0091 \\
\hline \multirow[t]{2}{*}{ Type of birth } & Single & $31.78^{A}$ & 1.24 & $0.7201^{\mathrm{A}}$ & 0.0154 & $0.2642^{\mathrm{A}}$ & 0.0012 \\
\hline & Twin & $35.96^{A}$ & 2.85 & $0.7267^{\mathrm{A}}$ & 0.0274 & $0.2599^{A}$ & 0.0073 \\
\hline \multirow[t]{4}{*}{ Flock } & Rakh Kheirewala & $34.44^{\mathrm{A}}$ & 2.52 & $0.9437^{c}$ & 0.0054 & $0.1288^{A}$ & 0.0074 \\
\hline & Rakh Ghulaman & $31.39^{A}$ & 2.38 & $0.9279^{B C}$ & 0.0073 & $0.1104^{\mathrm{A}}$ & 0.0113 \\
\hline & Alladad & $36.67^{A}$ & 2.89 & $0.91867^{\mathrm{B}}$ & 0.0113 & $0.1024^{\mathrm{A}}$ & 0.0299 \\
\hline & Bahadurnagar & $29.84^{\mathrm{A}}$ & 1.68 & $0.8966^{A}$ & 0.0299 & $0.1573^{A}$ & 0.0091 \\
\hline
\end{tabular}

a: predicted weight, b: turning point of growth, $\mathrm{k}$ : rate of growth, Means with uncommon letters differ significantly $(P<0.05)$.

Table 5

Single factor analysis for parameters in Gompertz model

\begin{tabular}{|c|c|c|c|c|c|c|c|}
\hline \multirow[t]{2}{*}{ Factor } & & \multicolumn{2}{|c|}{$a$} & \multicolumn{2}{|c|}{$b$} & \multicolumn{2}{|c|}{$k$} \\
\hline & & Constant & se & Constant & se & Constant & se \\
\hline \multirow[t]{2}{*}{ Sex } & Male & $24.13^{A}$ & 0.6408 & $0.7123^{A}$ & 0.0196 & $0.2750^{A}$ & 0.0107 \\
\hline & Female & $25.61^{A}$ & 0.6976 & $0.7345^{\mathrm{A}}$ & 0.0213 & $0.2492^{A}$ & 0.0116 \\
\hline \multirow[t]{2}{*}{ Type of birth } & Single & $25.23^{A}$ & 0.5048 & $0.7201^{A}$ & 0.0154 & $0.2642^{\mathrm{A}}$ & 0.0084 \\
\hline & Twin & $24.50^{\mathrm{A}}$ & 0.8945 & $0.7267^{\mathrm{A}}$ & 0.0274 & $0.2599^{\mathrm{A}}$ & 0.0149 \\
\hline \multirow[t]{4}{*}{ Flock } & Rakh Kheirewala & $24.46^{\mathrm{AB}}$ & 0.9411 & $0.8274^{\mathrm{A}}$ & 0.0288 & $0.2942^{A}$ & 0.0157 \\
\hline & Rakh Ghulaman & $24.12^{\mathrm{B}}$ & 0.9063 & $0.7761^{A}$ & 0.0277 & $0.2575^{A B}$ & 0.0151 \\
\hline & Alladad & $26.69^{A}$ & 0.9274 & $0.6700^{\mathrm{B}}$ & 0.0284 & $0.2283^{\mathrm{B}}$ & 0.0154 \\
\hline & Bahadurnagar & $24.19^{\mathrm{B}}$ & 0.8782 & $0.6199^{\mathrm{B}}$ & 0.0269 & $0.2684^{\mathrm{AB}}$ & 0.0146 \\
\hline
\end{tabular}

a: predicted weight, $b$ : turning point of growth, $k$ : rate of growth, Means with uncommon letters differ significantly $(P<0.05)$. 
Table 6

Parameters of growth curve in Brody model for Beetal goats

\begin{tabular}{llccccc}
\hline Farm & \multicolumn{5}{c}{ Parameter } \\
& & $\mathrm{a}$ & $\mathrm{b}$ & $\mathrm{k}$ & $\mathrm{R}^{2}$ & $\mathrm{se}$ \\
\hline Rakh Kheirewala & Male & $28.33 \pm 2.75$ & $0.9325 \pm 0.03$ & $0.141 \pm 0.03$ & 97.4 & 1.1220 \\
& Female & $33.77 \pm 4.84$ & $0.9471 \pm 0.01$ & $0.078 \pm 0.02$ & 98.9 & 0.6457 \\
& Combined & $29.76 \pm 3.25$ & $0.9376 \pm 0.02$ & $0.111 \pm 0.02$ & 98.4 & 0.8496 \\
Rakh Ghulaman & Male & $26.61 \pm 0.99$ & $0.9191 \pm 0.01$ & $0.126 \pm 0.01$ & 99.7 & 0.3275 \\
& Female & $29.76 \pm 3.25$ & $0.9376 \pm 0.02$ & $0.111 \pm 0.02$ & 98.4 & 0.8496 \\
& Combined & $27.95 \pm 1.04$ & $0.9253 \pm 0.01$ & $0.109 \pm 0.01$ & 99.8 & 0.2643 \\
Alladad & Male & $35.86 \pm 1.78$ & $0.9213 \pm 0.01$ & $0.084 \pm 0.01$ & 99.8 & 0.2756 \\
& Female & $30.45 \pm 1.24$ & $0.9033 \pm 0.01$ & $0.091 \pm 0.01$ & 99.9 & 0.2206 \\
& Combined & $33.56 \pm 1.26$ & $0.9141 \pm 0.00$ & $0.086 \pm 0.01$ & 99.9 & 0.2019 \\
Bahadurnagar & Male & $27.93 \pm 1.30$ & $0.8872 \pm 0.01$ & $0.125 \pm 0.01$ & 99.5 & 0.4253 \\
& Female & $26.97 \pm 1.16$ & $0.8850 \pm 0.01$ & $0.108 \pm 0.01$ & 99.8 & 0.2870 \\
Overall & Combined & $27.32 \pm 1.14$ & $0.8854 \pm 0.01$ & $0.117 \pm 0.01$ & 99.7 & 0.3305 \\
& Male & $28.91 \pm 1.30$ & $0.9137 \pm 0.01$ & $0.120 \pm 0.01$ & 99.6 & 0.3948 \\
& Female & $30.21 \pm 1.03$ & $0.9187 \pm 0.00$ & $0.091 \pm 0.01$ & 99.9 & 0.1845 \\
& Combined & $29.13 \pm 1.16$ & $0.9160 \pm 0.01$ & $0.108 \pm 0.01$ & 99.8 & 0.2858 \\
\hline
\end{tabular}

a: predicted weight, b: turning point of growth, $k$ : rate of growth

Table 7

Parameters of growth curve in Gompertz model for Beetal goats

\begin{tabular}{llccccc}
\hline Farm & Sex & \multicolumn{5}{c}{ Parameter } \\
& & $\mathrm{a}$ & $\mathrm{b}$ & $\mathrm{K}$ & $\mathrm{R}^{2}$ & $\mathrm{se}$ \\
\hline Rakh Kheirewala & Male & $24.20 \pm 0.96$ & $2.1395 \pm 0.17$ & $0.308 \pm 0.035$ & 98.3 & 0.9081 \\
& Female & $23.26 \pm 0.52$ & $2.2783 \pm 0.06$ & $0.250 \pm 0.012$ & 99.8 & 0.3117 \\
& Combined & $23.58 \pm 0.77$ & $2.1939 \pm 0.12$ & $0.281 \pm 0.023$ & 99.2 & 0.5977 \\
Rakh Ghulaman & Male & $22.09 \pm 0.39$ & $2.0315 \pm 0.06$ & $0.288 \pm 0.014$ & 99.7 & 0.3298 \\
& Female & $22.41 \pm 0.49$ & $2.1146 \pm 0.06$ & $0.253 \pm 0.013$ & 99.7 & 0.3134 \\
& Combined & $22.18 \pm 0.43$ & $2.0656 \pm 0.06$ & $0.271 \pm 0.013$ & 99.7 & 0.3193 \\
Alladad & Male & $26.60 \pm 0.68$ & $2.0020 \pm 0.05$ & $0.230 \pm 0.013$ & 99.7 & 0.3658 \\
& Female & $23.61 \pm 0.86$ & $1.8658 \pm 0.07$ & $0.226 \pm 0.018$ & 99.4 & 0.4609 \\
& Combined & $25.22 \pm 0.75$ & $1.9402 \pm 0.06$ & $0.228 \pm 0.014$ & 99.6 & 0.3981 \\
Bahadurnagar & Male & $23.78 \pm 0.79$ & $1.7976 \pm 0.08$ & $0.263 \pm 0.023$ & 99.1 & 0.5929 \\
& Female & $22.25 \pm 0.81$ & $1.7732 \pm 0.07$ & $0.238 \pm 0.021$ & 99.2 & 0.4997 \\
Overall & Combined & $22.98 \pm 0.78$ & $1.7848 \pm 0.08$ & $0.251 \pm 0.021$ & 99.3 & 0.5324 \\
& Male & $24.02 \pm 0.49$ & $1.9827 \pm 0.06$ & $0.272 \pm 0.014$ & 99.7 & 0.3727 \\
& Female & $22.94 \pm 0.47$ & $1.9900 \pm 0.04$ & $0.239 \pm 0.011$ & 99.8 & 0.2753 \\
& Combined & $23.45 \pm 0.46$ & $1.9837 \pm 0.05$ & $0.257 \pm 0.012$ & 99.8 & 0.3122 \\
\hline
\end{tabular}

a: predicted weight, b: turning point of growth, $k$ : rate of growth

\section{Discussion}

Growth is measured as increase in weight and this can be measured directly. Mathematical models interpret the underlying biological phenomena to variable degrees. The goodness of fit is one of the criteria to compare the models. In present study, the determination 
coefficients of Brody and Gompertz models were very high and quite similar $\left(R^{2}=99.79\right.$ and $99.76 \%$, respectively). The value of $\mathrm{R}^{2}$ was higher because one person recorded all the data around the year and animals were selected in the beginning of the study and closely monitored. These results were in accordance with Karakus et al. (2008) and Topal et al. (2004) who reported very high values of $\mathrm{R}^{2}$ for Brody's model (98.9 and 99.1). Malhado et al. (2009) and Tsukahara et al. (2008) reported slightly lower values of $\mathrm{R}^{2}$ for Brody's model. Corresponding results from Gompertz model matched with Malhado et al. (2009), Karakus et al. (2008), Topal et al. (2004) and Kor et al. (2006) reported $R^{2}$ ranging from 97.8 to 99.7 but Tsukahara et al. (2008) reported a slightly lower value $(93.7 \%)$ for this model. The present findings also matched with Akbas et al. (1999) who by comparing different models reported that Brody model had a good fit with highest $\mathrm{R}^{2}$.

In addition, the values of parameter «a« were 29.13 and 23.39 for Brody and Gompertz models, showed that Brody's model overestimated the parameter. These finding were inline with the findings of Malhado et al. (2009), Ozdemir \& Dellal (2009), Tatar et al. (2009), Tsukahara et al. (2008), Friggens et al. (1997) and Zygoyiannis et al. (1997) but were lower than the results of Karakus et al. (2008). The turning point in Gompertz model found in the present study matched with other findings (Malhado et al. 2009, Topal et al. 2004, Bathaei \& Leroy 1998) but maturing rate differed from these studies. Values of corresponding parameters in Brody's model as found in the present study coincided with results of other research workers (Malhado et al. 2009, Tsukahara et al. 2008, Bathaei \& Leroy 1998). The value of MAD for both models was quite lower than reported by Malhado et al. (2009).

Growth pattern in Beetal seemed similar to the other breeds studied by various workers. The growth curves when drawn for Brody and Gompertz models appeared similar in shape and also matched with the curves drawn by other researchers (Ozdemir \& Dellal 2009). The present results showed that mathematical functions of Brody and Gompertz had an excellent fit to the growth of Beetal male and female kids. The prediction of mature weight from a few monthly weights was apparent and similar to the findings of earlier researchers. Increase in weight with the passage of time was apparent in both sexes, starting from a very small birth weight to reaching a high value after one year of age, showing growth. But the growth was not altogether uniform at any interval. There were different phases but a smooth increase was obvious. Firstly, it increased at steady rate, then slowed down and declined for a short period. It again inclined after a bending and reached the maximum. The whole pattern of growth was somewhat like the so called »Sigmoid» fashion.

Brody and Gompertz mathematical functions explained growth of Beetal kids very well. The parameters in the model estimated by non-linear regression models provided excellent fit $(99 \%)$ for growth curve. The observed and predicted curves matched well. The growth curve can help planning farm management strategies and decision making regarding the culling of poor producers and selecting the highly productive animals just by viewing their growth curve. It is suggested that any of these models can be used for estimating growth curves of Beetal goats. 


\section{References}

Akbas Y, Taskin T, Demiroren E (1999) Comparison of several models to fit growth curves of Kivircik and Daglic male lambs. Turk J Vet Anim Sci 23, 537-544 [Abstract]

Bananno A, Alabiso M, di-Grigoli A, Di-Grogoli A (1997) Live performance of different genetic type lambs defined by growth curves. Zootecnica e Nutrizione Anim 23, 195-206

Bathaei SS, Leyroy PL (1998) Genetic and phenotypic aspects of the growth curve characteristics in Mehraban Iranian fat-tailed sheep. Small Rumin Res 29, 261-269

Bathaei SS, Leyroy PL (1996) Growth and mature weight of Mehraban Iranian fat-tailed sheep. Small Rumin Res 22, 155-162

Bertalanffy LV (1957) Quantitative laws in metabolism and Growth. Q Rev Biol 32, 217-230

Bhadula SK, Bhat PN (1980) Note on growth curve in sheep. Indian J Anim Sci 50, 1001-1003

Brody S (1945) Bioenergetics and Growth. Reinhold Publishing Corp, NY, USA

Eisen EJ (1976) Result of growth curve analysis in mice and rats. J Anim Sci 42, 1008-1023

Friggens NC, Shanks M, Kyriazakis I, Oldham JD, McClelland TH (1997) The growth and development of nine European sheep breeds. I. British breeds: Scottish Blackface, Welsh Mountain and Shetland. Anim Sci 65, 409-426

GOP (2006) Economic Survey of Pakistan 2006-07. http://www.finance.gov.pk/survey_0607.html [last accessed 28.06.2011]

Jenkins TG, Leymaster KA (1993) Estimating of maturing rates and masses at maturity for body components of sheep. J Anim Sci 71, 2952-2957

Karakus K, Eyduran E, Kum D, Ozdemir T, Cengiz F (2008) Determination of the best growth curve and measurement interval in Norduz male lambs. J Anim Vet Adv 7, 1464-1466

Kocabas Z, Kesici T, Elicin A (1997) Growth curves of Akkaraman, Awassi×Akkaraman and Malya×Akkaraman lambs. Turkish J Vet Anim Sci 21, 267-275

Kor A, Baspinar E, Karaca S, Keskin S (2006) The determination of growth in Akkeci (White goat) female kids by various growth models. Czech J Anim Sci 51, 110-116

Lambe NR, Navajas EA, Simm G, Bunger L (2006) A genetic investigation of various growth models to describe growth of lambs of two contrasting breeds. J Anim Sci 84, 2642-2654

Laird AK (1965) Dynamics of relative growth. Growth 29, 249-263

Malhado CHM, Carneiro PLS, Affonso PRAM, Souza Jr. AAO, Sarmento JLR (2009). Growth curves in Dorper sheep crossed with the local Brazilian breeds, Morada Nova, Rabo Largo and Santa Ines. Small Rumin Res 84, 16-21

Moore AJ (1986) A mathematical equation for animal growth from embryo to adult. Anim Prod 40, 441-453

Nashholm A, Danell O (1990) Growth and mature weight of Swedish Fine wool Landrace ewes. I. Growth curves and estimation of individual mature weight. Acta Agric Scan 40, 71-81

Nasholm A (1990) Mature weight of ewe as a trait in sheep breeding. In: Proc. 4th World Congress on Genetics Applied to Livestock Production, Genetics and Breeding Fiber, Fur and Meat Quality, Edinburgh, 154, 88-91

Nelder JA (1961) The fitting of a generalization of the logistic curve. Biometrics 17, 89-110

Ozdemir H, Dellal G (2009) Determination of growth curves in young Angora goats. Tarim Bilimleri Gergisi 15, 358-362

Richards FJ (1959) A flexible growth function for empirical use. J Exp Bot 10, 290-300

Sarmento JLR, Rezazzi AJ, Souza WH, Torres RA, Breda FC, Menezes GRO (2006) Estudo da curva de crescimento de ovinos Santa Ines, R Bras Zootec 35, 435-442

Salah MS, Basmael SM, Mogawer HH (1988) Growth curve in Aardi goats. Ardo Gulf J Sci Res, B Agric Bio Sci 6 , 369-379

Sherrod PH (2008) NLREG version 6.5. http://www.nlreg.com/ [last accessed 16.03.2011] 
SPSS (1999) Statistical Package for Social Sciences, SPSS for Windows Release 10.0. SPSS Inc. Chicago, USA

Tatar AM, Tekel N, Ozkan M, Baritci I, Dellal G (2009) The determination of growth function in young Hair goat. J Anim Vet Adv 8, 213-216

Tekel N, Sireli HD, Elicin M, Elicin A (2005) Comparison of growth curve models on Awassi lambs. Indian Vet J $82,179-182$

Topal M, Ozdemir M, Aksakal V, Yildiz N, Dogru U (2004) Determination of the best point nonlinear function in order to estimate growth in Morkaraman and Awassi lambs. Small Rumin Res 55, 229-232

Tsukahara Y, Chomei Y, Oishi K, Kahi AK, Panadam JM, Mukherjee TK, Hirooka H (2008) Analysis of growth pattern in purebred Kambing Katjang goat and its crosses with the German Fawn. Small Rumin Res 80, 78-15

Yeni H (2003) Genç Ankara Keçilerinde Büyüme Fonksiyonunun Belirlenmesi. Ankara University Natural Science Institute, Master Thesis, Ankara-Turkey

Zygoyiannis D, Kyriazakis I, Stamataris C, Freggens NC, Katsaounis N (1997) The growth and development of nine European sheep breeds. 2. Greek breeds: Boutsko, Serres and Karagounika. Anim Sci 5, 427-440

Received 23 June 2010, accepted 16 March 2011.

Corresponding author:

Abdul Waheed

email: dobaara@yahoo.com

Department of Animal Breeding and Genetics, Faculty of Animal Husbandry, University of Agriculture, Faisalabad 38070, Pakistan 